\title{
"Tools for formation and development of the environmentally friendly food products market: regional aspect in Ukraine"
}

\begin{tabular}{|c|c|}
\hline AUTHORS & $\begin{array}{l}\text { Victoriia Dergachova (D https://orcid.org/0000-0003-0317-8675 } \\
\text { Serhii Smerichevskyi (D https://orcid.org/0000-0003-2102-1524 } \\
\text { R https://publons.com/researcher/1930671/serhii-smerichevskyi/ } \\
\text { Tetiana Kniazieva (D https://orcid.org/0000-0002-4972-0055 } \\
\text { Svitlana Smerichevska (D http://orcid.org/0000-0003-0733-8525 } \\
\text { R https://publons.com/researcher/1594690/svitlana-smerichevska/ }\end{array}$ \\
\hline ARTICLE INFO & $\begin{array}{l}\text { Victoriia Dergachova, Serhii Smerichevskyi , Tetiana Kniazieva and Svitlana } \\
\text { Smerichevska (2020). Tools for formation and development of the } \\
\text { environmentally friendly food products market: regional aspect in Ukraine. } \\
\text { Environmental Economics, 11(1), 96-109. doi:10.21511/ee.11(1).2020.09 }\end{array}$ \\
\hline DOI & http://dx.doi.org/10.21511/ee.11(1).2020.09 \\
\hline RELEASED ON & Wednesday, 15 July 2020 \\
\hline RECEIVED ON & Saturday, 27 June 2020 \\
\hline ACCEPTED ON & Tuesday, 14 July 2020 \\
\hline LICENSE & $\begin{array}{l}(c) E Y \\
\text { This work is licensed under a Creative Commons Attribution } 4.0 \text { International } \\
\text { License }\end{array}$ \\
\hline JOURNAL & "Environmental Economics" \\
\hline ISSN PRINT & $1998-6041$ \\
\hline ISSN ONLINE & 1998-605X \\
\hline PUBLISHER & LLC "Consulting Publishing Company "Business Perspectives" \\
\hline FOUNDER & LLC "Consulting Publishing Company "Business Perspectives" \\
\hline
\end{tabular}

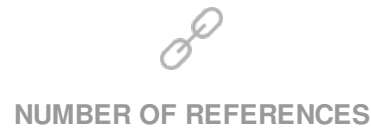

23
NUMBER OF FIGURES

6
NUMBER OF TABLES

2

(C) The author(s) 2022. This publication is an open access article. 


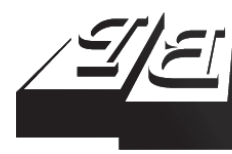

\section{BUSINESS PERSPECTIVES}

LLC "CPC "Business Perspectives" Hryhorii Skovoroda lane, 10, Sumy, 40022, Ukraine www.businessperspectives.org

Received on: $2^{\text {th }}$ of June, 2020 Accepted on: $14^{\text {th }}$ of July, 2020 Published on: $15^{\text {th }}$ of July, 2020

() Victoriia Dergachova, Serhii Smerichevskyi, Tetiana Kniazieva, Svitlana Smerichevska, 2020

Victoriia Dergachova, Doctor of Economics, Professor, Head of the Management Department, National Technical University of Ukraine "Igor Sikorsky Kyiv Polytechnic Institute", Ukraine.

Serhii Smerichevskyi, Doctor of Economics, Professor, Head of the Marketing Department, National Aviation University, Ukraine.

Tetiana Kniazieva, Doctor of Economics, Associate Professor, Professor of the International Economics Department, National Aviation University, Ukraine.

Svitlana Smerichevska, Doctor of Economics, Professor, Professor of the Logistics Department, National Aviation University, Ukraine.

Victoriia Dergachova (Ukraine), Serhii Smerichevskyi (Ukraine), Tetiana Kniazieva (Ukraine), Svitlana Smerichevska (Ukraine)

\title{
TOOLS FOR FORMATION
} AND DEVELOPMENT OF THE ENVIRONMENTALLY FRIENDLY FOOD PRODUCTS MARKET: REGIONAL ASPECT
IN UKRAINE

\begin{abstract}
Utilization of modern technologies in food production causes several negative consequences having a long-term impact on public health due to the consumption of food containing components of inorganic origin. This circumstance requires the formation and development of the market of organic food in Ukraine. The paper aims to substantiate the possibility of using economic and organizational tools to rationalize environmentally friendly food consumption and eliminate their negative consequences for the region's population. The study's basis is the classical provisions of modern economic theory, environmental economics, and the concept of socio-ethical marketing. Based on the analysis of official statistics, the parameters and opportunities for the growth of the organic food products market in Ukraine by region are determined. The conformity of the product offer of ecologically clean products to different consumer segments in the region is revealed according to the criteria that characterize the groups of goods according to the degree of their ecological purity compared to the price parameter frequency of purchase, and place of purchase. The priorities for the gradual expansion of the organic food market in the region have been determined with an emphasis on its expansion by attracting new consumer segments. The need for additional organizational measures in the region, aimed at both non-commercial and commercial promotion of healthy lifestyles and proper nutrition, is argued, which increases consumers involvement in these processes and increases awareness and interest in regular consumption of organic food.
\end{abstract}

\section{Keywords}

JEL Classification

\section{INTRODUCTION}

The main trend of today is to increase the importance of socio-ethi$\mathrm{cal}$ aspects in transactional processes and increase the number of exchange relations' parties. This necessitates a harmonious combination of the interests of producers, intermediate and final consumers and society as a whole, which raises the question of increasing corporate social responsibility. As a result, we note the increasing role of socialethical marketing as a methodological study rules and regulations operation of business in modern conditions. In this sense, the need for a partial revision of conceptual approaches in applying economic and organizational tools in terms of greater emphasis on social and environmental aspects seems timely and relevant. 
At the beginning of the study, it was suggested that the use of economic and organizational tools within the concept of socio-ethical marketing and marketing of "green" technologies would quickly take into account the dynamics of solvent demand for environmentally friendly products in each region based on official statistics and adjusting them through field research. The study of the dynamics of solvent demand for organic products becomes the basis for the formation of market supply, differentiated by the degree of environmental friendliness of products to enhance the potential of regions in the organic food market and rationalize the consumption of organic food.

\section{LITERATURE REVIEW}

A study of the growing needs and consumption of resources to provide for the world's population was commissioned in 1968 by Jay Wright Forrester at the Club of Rome (Lane, 2006). In 1972, thanks to Dennis L. Meadows and a group of scientists (Donella H. Meadows, Jorgen Randers, William W. Behrens III), the facts were published that while maintaining current trends in economic growth at the end of the necessary resources, the next generations of humankind will reach the limits of demographic and economic expansion, which will invariably lead humanity to the crisis (Meadows, 1977). Currently, the term "sustainable development" of humankind is more often used, in which the search for a model of world civilization development is based on "meeting the vital needs of the current economic generation without depriving future generations of such an opportunity" (WCED, 1987).

The UN World Conference on Environment and Development (Rio de Janeiro in 1992) stated that "One of the main causes of persistent environmental degradation worldwide is a structure of consumption and production that does not provide sustainability, especially in industrialized countries. Excessive claims and wasteful lifestyles of the richest part of humanity place a huge burden on the environment" (UN, 1992). As adherence to the basic principles called for by the participants of this conference was the development of national strategies for correcting the patterns of consumer behavior to rationalize them. Further, the UN World Summit on Sustainable Development (Johannesburg, 2002) adopted an agreement regulating the conditions for sustainable production and consumption of goods, which calls for the rationalization of this process in humankind's interests.

Scientific positions in this area are formed based on the study, analysis, and development of foreign and domestic researchers' theoretical and methodological works in marketing, management, and environmental economics. The fundamental foundations of the "green" economy and its tools are laid in the works of Ukrainian authors T. Galushkina, V. Potapenko, O. Prokopenko, S. Kharichkov, Ye. Khlobystov who studied the problem of the evolution of marketing towards a socially-oriented concept, marketing partnerships, relationship marketing.

The analysis of the environmental marketing's potential, development of its tools and formulation and implementation of "green" marketing strategies in companies, as well as analysis of consumption of organic food is presented in the works of foreign scientists such as S. Athanasius, B. Bekti Retnawati, J. P. Govender, T. L. Govender, M. Hayu Agustini, P. Kumar, B. M. Ghodeswar, C.-J. H.-Y. Lin Chen, E. Williams. Despite the great contribution to the above problems of the above scientists, it should be noted that the formation and development of the market of organic food in the region with the involvement of economic and organizational tools are not properly reflected in the scientific literature, which highlights the need for this study.

At present, there is no doubt that excessive, irrational consumption of goods leads to a reduction in resources and, consequently, exacerbates environmental problems, leading to a decrease in the quality of life of the world's population. These circumstances are of interest and relevance in the practical application of environmental marketing tools, which is understood as the process of meeting consumer needs by promoting goods and services that cause minimal damage to the environment at all stages of the life cycle and created with the minimum possible volume of natural resources.

Specifying the mentioned decision, a warning should be made that there are different ways to 
cause minimal damage to nature: one can reduce energy consumption in the production of something, one can pack intermediate and final products so that they will cause less harm to the environment, one can reduce hazardous waste, it is possible to reduce the total amount of waste, which will also be a tool from the arsenal of environmental marketing, one can restore the resources used and re-use them, both in production and consumption. In addition to the definition of environmental marketing in the literature, there is the term "marketing of "green" technologies", which is used in several foreign sources (Mueller, 2017; Williams, 2011). Thus, due to the strengthening of environmental legislation, which sets a fee for eliminating industrial waste, production technologies, which result in a large amount of waste, become unprofitable. On the contrary, those technologies are cost-effective that use energy and resources economically, with minimal waste. Such technologies reduce the negative impact on the environment and are called "green technologies".

Production modernization processes that reduce consumption and minimize waste can be very costly and are not covered by the expected subsidies and fines. Thus, products produced by "green" technology can be more expensive and, accordingly, lose price competition to companies that do not use "green" technology. In this case, a socially responsible business that uses "green" technology needs management and marketing support to focus consumers on "green" products, albeit slightly more expensive but produced by environmentally friendly technologies. This is possible by addressing the sense of social responsibility of consumers.

It should be noted that the opportunity to appeal to the sense of social responsibility of consumers present in prosperous countries and designed for consumers who have the opportunity to pay more for the proposed "green" products. Among consumers of this kind, for example, in the United States, about $12 \%$ of respondents do it constantly, about $70 \%$ - do it occasionally, $18 \%$ - ignore such appeals to themselves (J. P. Govender \& T. L. Govender, 2016).

In summary, we should note that there should be a clear movement in the theory and practice of marketing from classical marketing to marketing partnerships and socio-ethical marketing. These metamorphoses are due to changes in the driving forces of economic development and are a steady trend of recent decades, have no alternative in the medium term. In this context, the vector of environmental marketing and its component in the form of marketing of environmentally friendly products creates a trend to increase the quality of life of Ukraine's population, which can be traced on the food market example, namely the production of organic (environmentally friendly) food.

The paper aims to substantiate the possibility of using economic and organizational tools to rationalize environmentally friendly food consumption and eliminate their negative consequences for the region's population in Ukraine.

Research methods. The theoretical basis of the study is the classical provisions of modern economic theory, economics of nature, the concept of socio-ethical marketing.

The working hypothesis of the research is based on the fact that the use of economic tools in the marketing of organic food will allow:

1) promptly take into account the dynamics of effective demand and the needs of different segments of the population in organic food;

2) to form a market-oriented offer of environmentally friendly products to activate the potential of the region in the market of organic food;

3) develop directions for rationalizing the consumption of organic food to minimize possible negative consequences for society and the environment.

Confirmation of the author's hypothesis of the research necessitated the involvement of procedures of logical and statistical analysis, graphical method of data display, method of office marketing research, synthesis, and averaging of the obtained results. Creative application of these scientific knowledge methods allowed to ensure the impartiality and reliability of the results of the analysis and synthesis of the obtained data to formulate several theoretical conclusions and practical proposals. 


\section{RESULTS}

\subsection{Organic production in Ukraine: regional aspects}

As often happens, import terminology is not fully understood in Ukraine. Many producers, sellers, and consumers define and distinguish between organic, eco-, and bio-products. These three terms are synonymous. Products without chemical additives are named in different countries in their own way. The term "organic products" is used in the United States, Britain, and Japan, "eco" - is typical of the Netherlands and the Scandinavian countries. The prefix "bio" is used in Germany and France. The movement of environmentally friendly goods began in the west in the 60s of the last century. For Ukraine, this phenomenon is considered relatively new.

Ukraine is the country with the largest reserves of quality fertile lands, so the agro-industrial sector's development is significant, and the share of agricultural products in total GDP is quite high. At the same time, in recent years, the market of traditional agricultural products and the market of organic agricultural products is growing. Increasing organic production to $10 \%$ of total gross agricultural output and introducing into national legislation agro-environmental standards and regulations of the European Union (including in the field of organic products) was part of Ukraine's rapprochement program with the European Union. Therefore, many norms of Ukrainian legislation almost literally quote the relevant EU directives. The set of international food standards of the WHO was also taken into account.

Since 2014, Ukraine's government has developed the necessary national standards and regulations, technical regulations, prepared documentation on zoning areas with relevant agro-environmental indicators, procedures for assessing such areas, created certification bodies for organic products, control bodies in this area, etc. Thus, today in Ukraine, the system of production, certification, and control over organic products is fully operational.

As the state statistics bodies do not currently conduct statistical reporting in the field of organic production, according to the Office for Support of Reforms at the Ministry of Economic Development, Trade and Agriculture of Ukraine in 2018-2019, the total area of agricultural land with organic status and the transition was about 309.1 thousand hectares $(0.7 \%$ of the total area of agricultural land in Ukraine). Simultaneously, there were 635 operators of the organic market, of which 501 were agricultural producers (Ahropromyslovyi kompleks Ukrainy (Agro-industrial complex of Ukraine), n.d.; State Statistics Service of Ukraine, 2019a). The main types of organic products produced in Ukraine are cereals, milk and dairy products, groats, meat and meat products, fruits and vegetables. Most operators of organic products in Kyiv and Kyiv region. It is also the south regions - Odesa and Kherson regions.

Ukrainian organic products are bought mainly by the EU countries, to which 266.7 thousand tons of products were exported in 2018. Thus, the largest consumers of domestic organic products are the Netherlands, Germany, USA, Switzerland, Italy, Great Britain, Austria, Poland, Czech Republic, France, Hungary, Romania, Belgium, Bulgaria, Lithuania, Canada and Denmark (State Statistics Service of Ukraine, 2019b). Ukrainian producers also export to Australia and some Asian countries. The main export products are cereals, oilseeds, berries, mushrooms, nuts, and fruits. Sunflower cake, flour, sunflower oil, sunflower meal, apple concentrate, and birch sap are also exported.

In 2018, the Law of Ukraine "On Basic Principles and Requirements for Organic Production, Circulation and Labeling of Organic Products" was adopted, which came into force on August 2, 2019. Currently, the Ministry is working on the development and implementation of 12 regulations provided by law. Today, the Ministry of Economic Development, Trade and Agriculture of Ukraine cooperates with international projects aimed at developing organic production, in particular with:

1. The project "German-Ukrainian cooperation in the field of organic farming".

2. Swiss-Ukrainian program "Development of trade with higher added value in the organic and dairy sectors of Ukraine". 
3. EU project "Support to the implementation of agricultural and food policy in Ukraine". Representatives of the projects take an active part in developing the regulatory framework in the field of organic production.

The certified organic market started its activity in Ukraine in 2006. Since then, it has shown some growth. So in 2008, its capacity amounted to EUR 600 thousand. In 2011 there was a significant increase. The total capacity was EUR 5.1 million. The positive trend continued the following year and was interrupted after the Dignity Revolution in 2013-2014. Then there was a certain decline. The situation began to gradually stabilize after 2015 (Mostovaya, 2017).

State support programs for organic producers have already been introduced in the regions of Ukraine. As of the beginning of 2019, the programs operated in 7 regions (Volyn, Zhytomyr, Lviv, Poltava, Rivne, Sumy, Chernihiv), in 4 regions this compensation was provided (Zakarpattia, IvanoFrankivsk, Khmelnytskyi, Chernivtsi), but there was no funding. Not all areas have made full use of these funds, the request must come directly from the manufacturer, and not all manufacturers want to deal with a stack of papers and delve into the procedures, even with significant benefits for themselves.

The state support program provides subsidies in the form of direct payments to cattle, organic poultry, and beekeeping; compensation of the certification process according to the national organic standard; subsidies through direct payments per hectare for perennial crops, gardens, shrubs.

\subsection{Research of potential capacity and market segmentation of environmentally friendly products in Ukraine}

The analysis of the experience of production and promotion of organic products in industrialized countries allows concluding that the production of organic food is much more expensive, requires special conditions and the availability of certain transport opportunities to deliver these products to intermediate and final consumers, in condi- tions that do not reduce the initial qualities of environmentally friendly products.

According to the producers of eco-products, rich people, intellectuals, and young people who strive for everything new are the main consumers of environmentally friendly products. Most often, organic goods are bought for the little ones. Price has a significant impact on consumer demand. Organic foods are more expensive. Abroad, their cost is higher by $15-20 \%$ of the price of alternative goods. It is much less common to find an overstatement of 50\%. Ukraine's pricing policy differs significantly. The difference in price can reach 200-300\%. Of course, this scares many buyers. On the one hand, overstatement can be speculative. Another reason lies in the workflow. Organic production requires a lot of manual labor. It is quite laborious and expensive. However, according to official data, the demand for organic in Ukraine is growing by $2.4 \%$ annually. According to opinion polls, $54 \%$ of compatriots are willing to overpay for environmentally friendly products. However, they are not going to pay more than $20 \%$. Only $13.5 \%$ of respondents refuse organic because they have their own gardens and orchards. To assess the prospects for the development of the market for environmentally friendly products in Ukraine, it is necessary to assess income level (Figure 1).

Statistics show that the share of the wealthy and middle class in Ukraine according to 2018-2019 is less than $2 \%$, which mirrors the data on the market volume for organic products from the total food market. Thus, statistics show that the organic segment's share of sales does not exceed $1 \%$ of total food sales. In Europe, this figure is 5\%. Abroad, the growth in demand for organics is growing by about $8-10 \%$ per year. The trend towards environmental friendliness is more popular in the United States. Such products are consumed by more than $40 \%$ of the population (Mostovaya, 2017).

Table 1 shows the indicators of households' distribution with children according to the self-assessment of their income level. This criterion was chosen for analysis because, as mentioned above, many consumers of organic products are willing to buy organic products just for their children, regardless of its cost. Figure 1 shows that the target segment of consumers of organic products is persons who consid- 


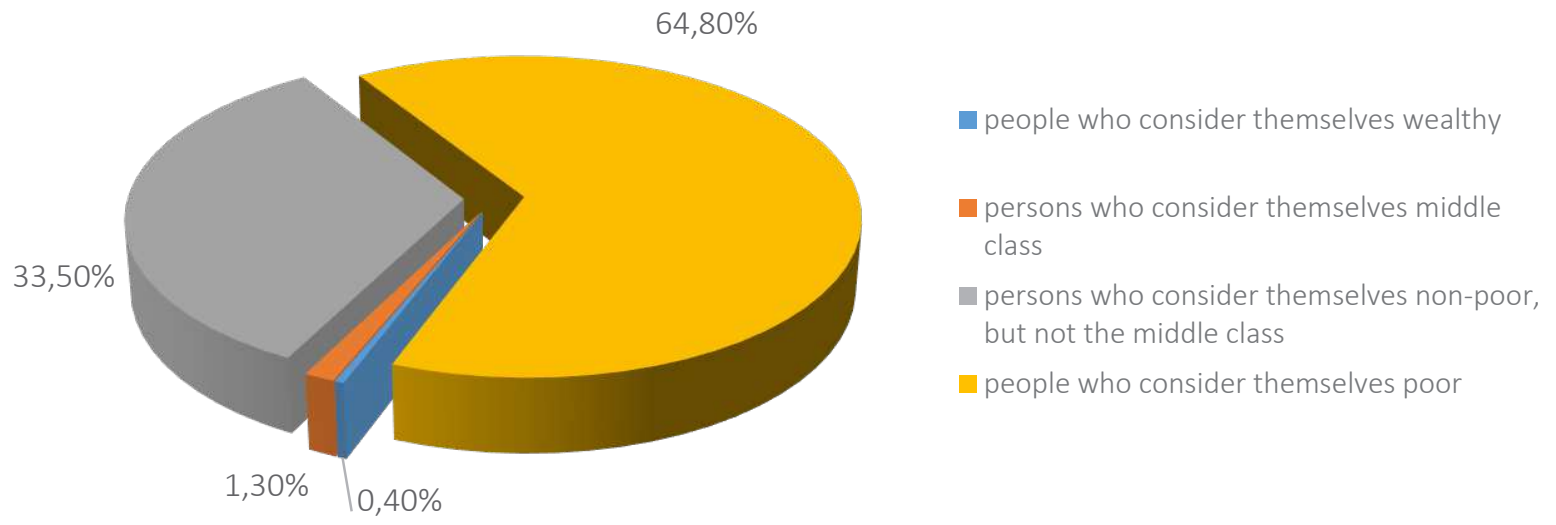

Figure 1. Distribution of households by self-assessment of material well-being, \%

er themselves middle class $(1,3 \%)$ and persons who consider themselves non-poor, but not the middle class (33,5\%). These consumer segments are analyzed in detail by income level in table. 1 . Official statistics show that a large segment of consumers who have a monthly income exceeds UAH 10,000.

Thus, the main consumers of organic products are aware of the harm of consuming inorganic products, who have access to organic food outlets regularly, who wish to buy organic food and have the appropriate economic opportunities regularly. If the first three conditions can be attributed to any member of society, the level of income, which determines the standard of living, significantly narrows the number of potential consumers. Certain criteria allow, with a high probability, to attribute a potential consumer of organic food to the middle class. Since consumer awareness of the harm of purchased food that does not have an organic certificate, means a certain approach to the assimilation of information, which implies a certain level of education, involvement in any social activities, social responsibility, from which arises a certain level of responsibility for their health and the health of their loved ones. Perceiving the value of your health and your loved ones' health as a resource means realizing the need to resort to the use of as few harmful products as possible. The criterion of affordability is also best suited to the capabilities of the middle class. Given the higher price range of organic products, the willingness to incur additional costs to cover the price premium for its consumption is also best suited to the middle class's capabilities. Based on the study results, it is proposed to identify the following segments of the population for their supply of environmentally friendly products (Figure 2).

Table 1. Distribution of households with children according to self-assessment of their income level (indicator for the beginning of 2019)

Source: Compiled by the authors for State Statistics Service of Ukraine (2019c).

\begin{tabular}{|c|c|c|c|}
\hline \multicolumn{2}{|c|}{$\begin{array}{c}\text { Distribution of households by average per capita income, } \\
\text { which according to households corresponds to the } \\
\text { property status of the middle class }\end{array}$} & \multicolumn{2}{|c|}{$\begin{array}{l}\text { Distribution of households by average per capita income } \\
\text { that the household considers sufficient not to feel poor }\end{array}$} \\
\hline UAH & $\%$ & $\mathrm{UAH}$ & $\%$ \\
\hline Up to $6,000.0$ & 0.6 & Up to $2,000.0$ & 0.4 \\
\hline $6,000.1-8,000.0$ & 1.2 & $2,000.1-3,000.0$ & 1.6 \\
\hline $8,000.1-10,000.0$ & 4.5 & $3,000.1-4,000.0$ & 2.4 \\
\hline $10,000.1-12,000.0$ & 3.3 & $4,000.1-5,000.0$ & 9.1 \\
\hline $12,000.1-14,000.0$ & 0.5 & $5,000.1-6,000.0$ & 5.3 \\
\hline $14,000.1-16,000.0$ & 12.3 & $6,000.1-7,000.0$ & 5.6 \\
\hline $16,000.1-18,000.0$ & 3.3 & $7,000.1-8,000.0$ & 11.0 \\
\hline $18,000.1-20,000.0$ & 15.9 & $8,000.1-9,000.0$ & 1.9 \\
\hline $20,000.1-22,000.0$ & 0.7 & $9,000.1-10,000.0$ & 27.7 \\
\hline Over $22,000.0$ & 57.7 & Over $10,000.0$ & 35.0 \\
\hline
\end{tabular}


Segments of the population in the region that are allocated to offer them organic food

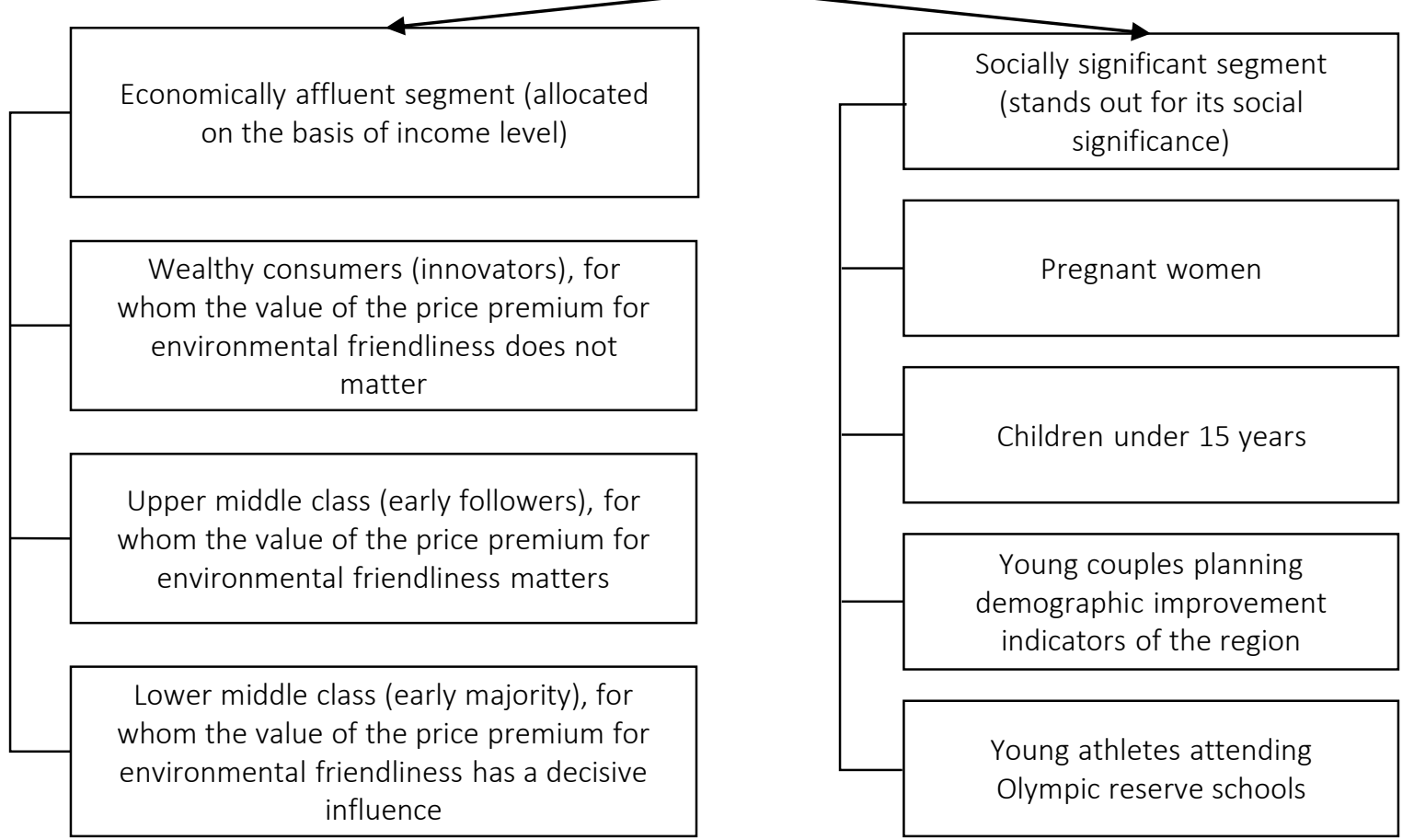

Figure 2. Segments of the population in the region that are allocated to offer them organic food

An idea of the size of certain segments can be obtained based on official static data and expert assessments, which is the purpose of future research. It can be reasonably assumed that providing such a large population with environmentally friendly food in the region in the absence of a relevant market is not possible shortly. Therefore, the only correct course of action in terms of this market's formation is the following approach, which involves development in two directions. The first direction is to provide environmentally friendly food products to socially significant segments of the region's population (pregnant women, future parents, young athletes, and organized children). The second direction is to provide organic food products to the region's economically prosperous population, which can afford to consume such products regularly.

\subsection{The development of the regional market of environmentally friendly food products in Ukraine}

To assess the economically wealthy population of Ukraine's regions, the authors present the data
(Figure 3) that reflect the regional distribution of Ukrainian households, whose members consider themselves to be middle class (in the second direction of development of the regional market of eco-products).

These data show that the most promising regions of Ukraine for the development of the organic food market are: Capital Economic Region (Kyiv, Chernihiv, Zhytomyr regions); Central Economic Region (Kirovohrad, Cherkasy regions); Prydniprovskyi economic region (Zaporizhzhia, Dnipropetrovsk regions) and Carpathian economic region (Lviv, Ivano-Frankivsk, Zakarpattia, Chernivtsi regions.

In terms of market formation is the most important to ensure demand for the proposed environmentally friendly products. As practice shows, there is no clear idea among the majority of the population that they eat and purchased everywhere food is not environmentally friendly and can pose a certain health risk, both immediately after consumption and in the long run (impact on 
Source: Compiled by the authors for State Statistics Service of Ukraine (2019b, 2019c).
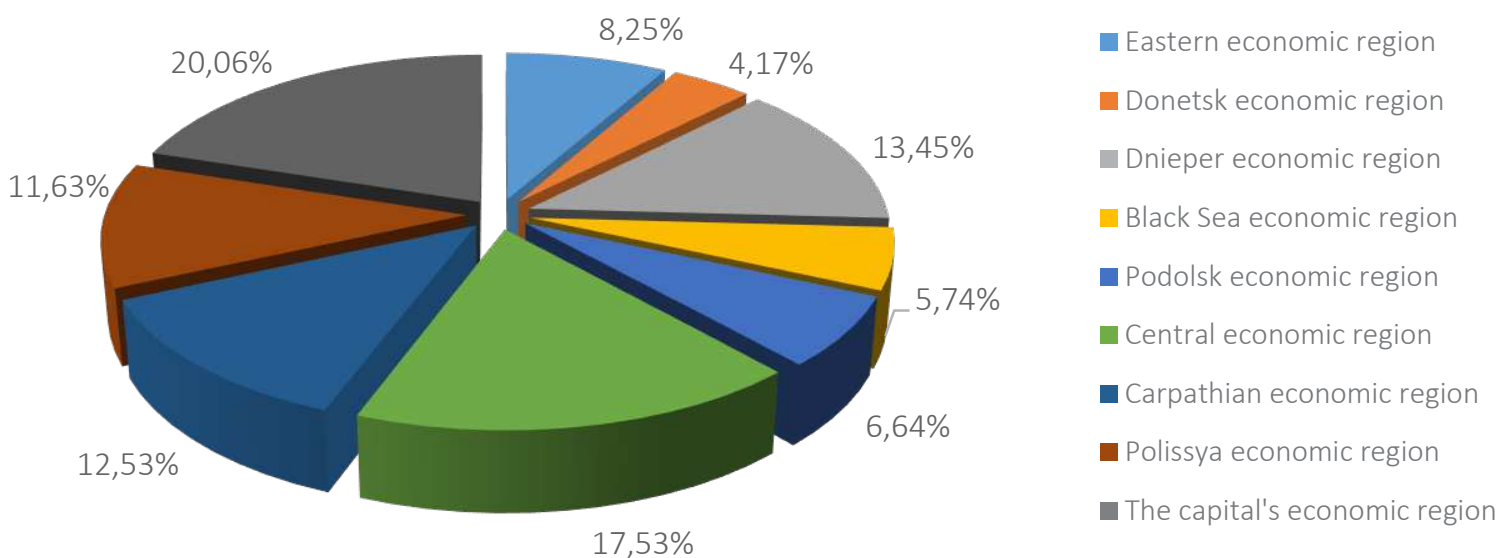

Figure 3. Regional distribution of Ukrainian households whose members identify themselves as middle class

immunity, allergenicity, reproduction, acceleration processes). The vast majority of respondents believe that if the goods are sold in a store, they cannot be harmful to health in compliance with the terms of sale and storage. Thus, consumers do not have a complete idea that their food may contain residues of plant protection products, pesticides, livestock growth stimulants. There is no information support on the range of issues presented. Organizational tools manifest themselves in administrative measures to inform (mandatory or voluntary) consumers, i.e., implemented through communication marketing tools.

The task of raising the level of informing (awareness) of potential consumers can be divided into stages, each of which involves the use of a set of elements of marketing communications (PR, social advertising (on personal media), commercial ad- vertising, sales promotion measures), visualized in Figure 4.

Measures to implement the first stage involve some "demonization" of traditional foods in potential consumers' opinions. This implies a flow of objective negative information about foods currently in retail regularly. This information can be communicated to the potential consumer through such channels that provide maximum audience coverage.

Moving on to the conditional second stage of raising the awareness of potential consumers, it is necessary to obtain objective information about the existence of food not containing harmful impurities in the form of residues of pesticides and growth promoters or products containing these impurities in minimal concentrations. In the

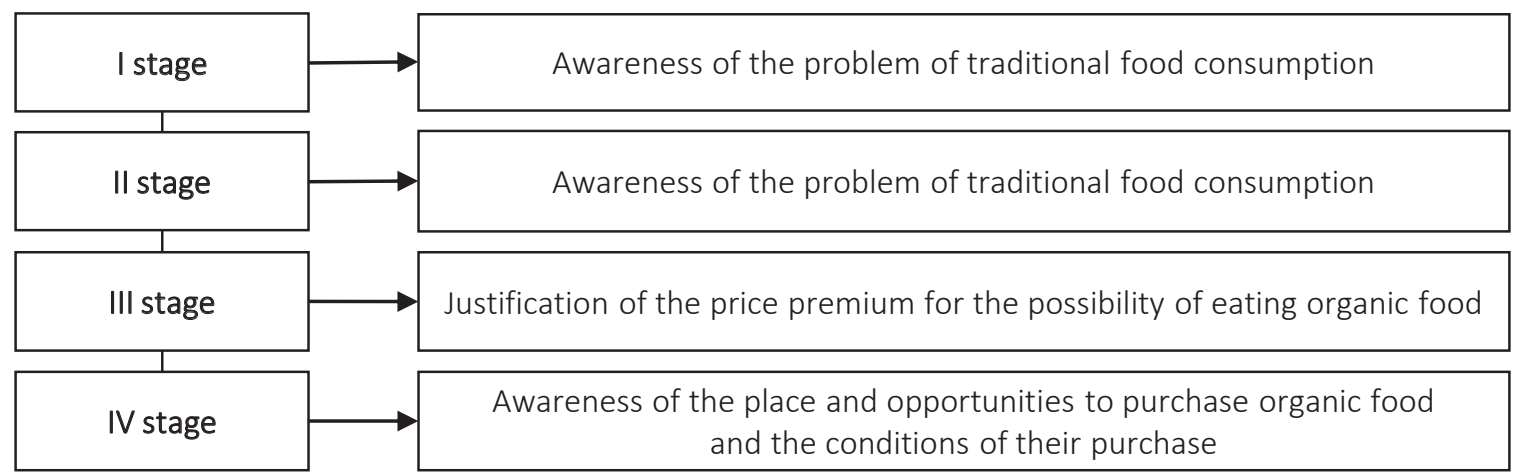

Figure 4. Stages of the process of raising awareness of potential consumers about the possibility of purchasing organic food 
third stage, it is necessary to justify the need for potential consumers of higher payments for products with higher quality parameters, namely environmental performance. The process of justifying the payment of a price premium, especially if its size differs from traditional products by more than $30-50 \%$, is complex and lengthy and requires efforts in positioning and information support of the validity of such practices in pricing. At the fourth stage, informing potential consumers is brought to a logical conclusion. Potential customers must have clear and reliable information about the availability of any product items of organic food, places of sale, and selling prices. This information should be presented widely enough on various media, encouraging the acquisition. In addition to the awareness of potential consumers, the organic food market formation involves many organizational measures.

To become a producer of organic products, one needs to go through a complex and expensive certification procedure. For example, can a grandmother in the village become a producer of organic eggs and meat? Unlikely, because she must pass an inspection by an authorized certification body and ensure that her chickens have not eaten grain treated with pesticides. This body checks whether organic seeds have been used, whether the products have been treated with pesticides, whether the products in the warehouse have been in contact with inorganic goods, whether harmful substances could have entered the packaging. The company must pay for certification UAH 6070 thousand and confirm an organic producer's status, depending on the type of activity on average once a year. The duration of production certification depends on the industry. For example, a certificate for grown organic strawberries must be waited for at least three years. Certification of pastures and fields with annual plants lasts at least 24 months, with perennial plants - 36 months, livestock farms (meat) and horses - year, goats, pigs and cows (milk) - six months, poultry (meat) ten weeks (Pirozhok, 2019).

There is considerable potential for conducting such examinations, which are not currently involved. As a resource to intensify independent examinations, research organizations in each region should be actively involved, which have the neces- sary research base. As part of the intensification of the use of organizational and economic tools in this area, a kind of food quality expertise center can be established, which studies a paid basis, according to pre-determined parameters based on scientific institutions available to legal entities and individuals in regional centers. For this purpose, laboratories can be organized at the centers of the State Sanitary and Epidemiological Service of Ukraine (restoration of which began in 2020 during the COVID-19 pandemic), which provide an opportunity to know the content of pesticides, antibiotics, nitrates, hormones, soy and more. This practice will attract additional funds to scientific organizations in each area and potential food consumers to gain access to reliable information about the quality parameters and environmental friendliness of purchased food. In addition to direct consumers of food in the services of such centers, trade organizations involved in the sale of food will be interested, of course, as the opportunity to provide consumers with information that the product meets the stated parameters and has the qualities of environmental friendliness, will help build trust with customers and increasing their commitment to a particular outlet.

A concrete measure from the arsenal of state regulation should be effective control over compliance with the rules of voluntary certification of products of its real quality at the regional level. Accordingly, the manufacturer should not arbitrarily change the announced products' quality without prior notice to potential consumers and the reseller (retail). Also, the manufacturer should not have the right to assign the name of the product organic without the corresponding confirmation by the center of the regional examination carried out systematically. Simultaneously, the process of food quality certification in the region should not turn into a kind of measures to promote certain brands. To do this, it is possible to involve members of the public and volunteers in the supervisory boards to provide transparency to the processes of food quality certification and periodic inspections, to prevent silence when negative indicators are identified, which necessitates the creation of a regional center for ecological food purity (Figure 5).

The above measures are shown to raise awareness of potential consumers, and organizational meas- 
ures for the examination and quality control of food consumed, of course, affect the formation of the regional market of environmentally friendly products. However, it is important to identify reserves to increase the production of such products. In this regard, it can be pointed out that it is promising to involve regional research centers' capacity to advise agricultural producers on increasing its environmental friendliness.

The products of enterprises producing organic products may also differ in the degree of environmental friendliness. Some groups of farms produce products that are close to such organic foreign products, which produce something that is not so organic but exceeds the average market, others bring to market products that meet the usual traditional, which is not environmentally friendly. The meaning of differentiation of food products based on examination of its quality is that there is an opportunity to recommend products of different farms to different segments of the population and, on the other hand, there is an opportunity to stimulate farms that produce more friendly products from an environmental point of view.

Upon completing the process of examination and certification of food products according to the degree of ecological purity, one can proceed to the recommendations on its proposal. Thus, products with the highest environmental friendliness (category I) should be recommended to pregnant women, couples who will have children, and young athletes. Products that are fairly friendly but laboratory compromised (category II) should be recommended for children's teams. In addition to the above criteria, it should be borne in mind that the segment of pregnant women, expectant parents,

Source: Developed by the authors.

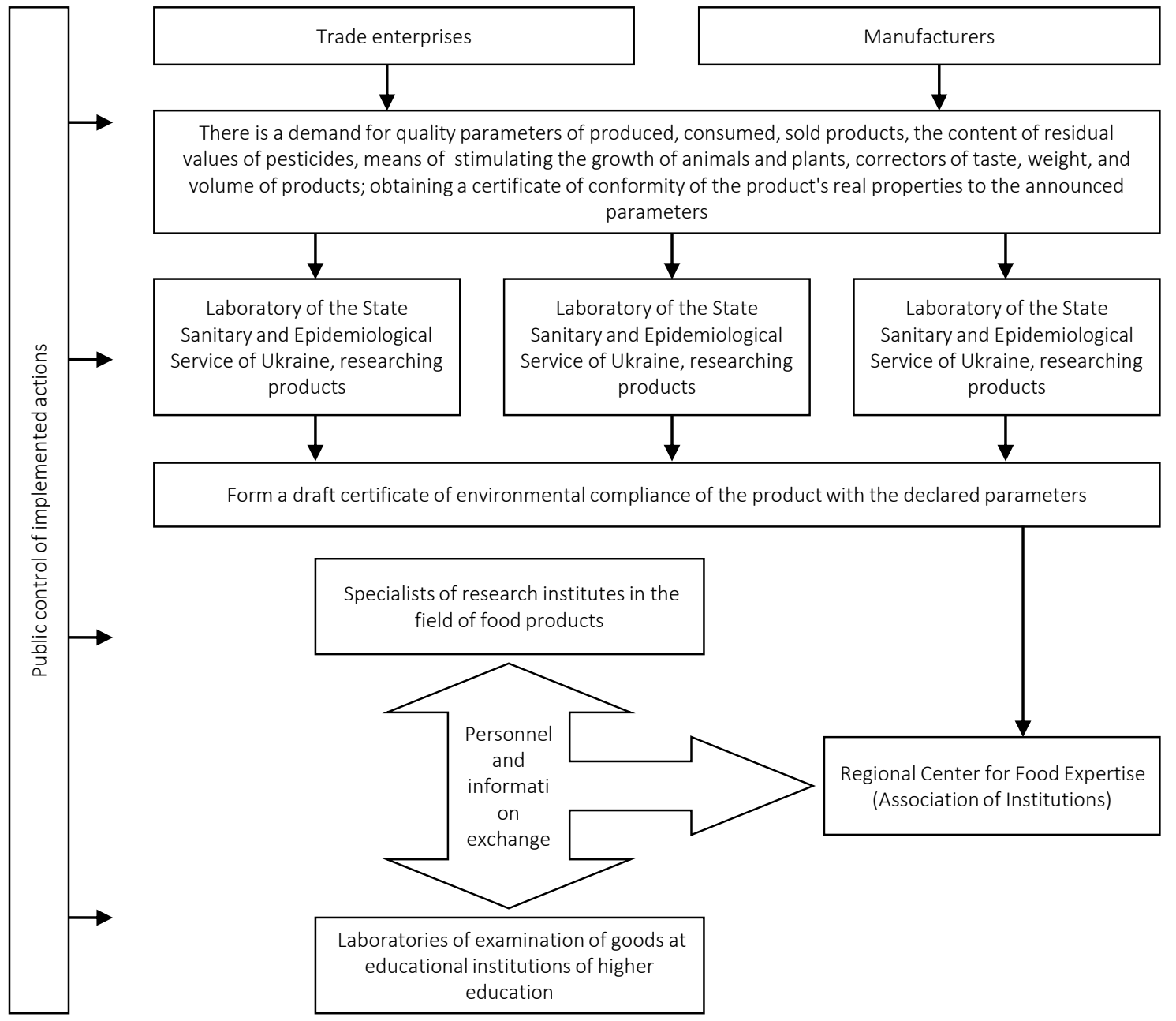

Figure 5. Scheme of the regional center for examination of food products ecological purity 
Table 2. Correspondence of food groups to different consumer segments

Source: Developed by the authors.

\begin{tabular}{|c|c|c|c|}
\hline $\begin{array}{l}\text { Consumer segment } \\
\text { distinguished by } \\
\text { income level }\end{array}$ & Characteristics of food products & $\begin{array}{l}\text { Frequency of } \\
\text { purchase }\end{array}$ & $\begin{array}{l}\text { Place purchase of } \\
\text { environmentally friendly food }\end{array}$ \\
\hline $\begin{array}{l}\text { Wealthy (premium) } \\
\text { consumers }\end{array}$ & $\begin{array}{l}\text { Organic food (organic) from Europe with } \\
\text { certificates }\end{array}$ & Regular & $\begin{array}{c}\text { Eco-friendly premium supermarket } \\
\text { with a high price gradient }\end{array}$ \\
\hline \multirow[b]{2}{*}{$\begin{array}{l}\text { The upper layer of the } \\
\text { middle class }\end{array}$} & $\begin{array}{l}\text { Organic food (organic) from Europe with } \\
\text { certificates }\end{array}$ & Irregular & $\begin{array}{l}\text { Eco-friendly premium supermarket } \\
\text { with a high price gradient }\end{array}$ \\
\hline & $\begin{array}{l}\text { Products containing minimum impurities, } \\
\text { substantially free of pesticides and measures } \\
\text { to promote plants and animals' growth, } \\
\text { approaching the degree of purity in organic } \\
\text { products, but without a certificate on the quality } \\
\text { of water and soil (products of category I) }\end{array}$ & Regular & Ecological bio-boutiques \\
\hline \multirow{3}{*}{$\begin{array}{l}\text { The lower layer of the } \\
\text { middle class }\end{array}$} & $\begin{array}{l}\text { Organic food (organic) from Europe with } \\
\text { certificates }\end{array}$ & $\begin{array}{l}\text { Rarely (on } \\
\text { holidays) }\end{array}$ & $\begin{array}{l}\text { Eco-friendly premium supermarket } \\
\text { with a high price gradient }\end{array}$ \\
\hline & $\begin{array}{l}\text { Products containing minimum impurities, } \\
\text { substantially free of pesticides and measures } \\
\text { to promote plants and animals' growth, } \\
\text { approaching the degree of purity in organic } \\
\text { products, but without a certificate on the quality } \\
\text { of water and soil (products of category I) }\end{array}$ & Periodically & $\begin{array}{c}\text { Ecological bio-boutiques } \\
\text { Fairs of environmentally friendly } \\
\text { products }\end{array}$ \\
\hline & $\begin{array}{l}\text { Products containing residues of pesticides } \\
\text { and plant growth stimulants in a small degree, } \\
\text { practically harmless to human health and } \\
\text { determined only by laboratory methods } \\
\text { (products of category II) }\end{array}$ & Regular & $\begin{array}{l}\text { Agricultural fairs } \\
\text { Self-pickup from the place of } \\
\text { production }\end{array}$ \\
\hline
\end{tabular}

and young athletes of the Olympic team reserve is quite small, and it will likely have enough products produced in this category. The segment of organized children is quite large, so its needs can be used products from category I and possible residues from category II.

As a result of such certification and correlation of selected segments of the population, the authors believe that environmentally friendly products for these groups will achieve certain benefits for public health and demographic improvement. On the other hand, producers will be involved in offering more environmentally friendly products, receiving additional preferences for it. The correlation of consumer groups from the socially significant segment with differentiated products is presented in Table 2.

Further expansion of the organic food market can take place in each of the elements of the created sales infrastructure due to constant and persistent activities to raise awareness of existing and potential consumers about the desirability of such practices for their health. The functioning of the market for organic products in the region will reveal certain benefits for producers involved in producing organic products and will help involve other food producers in this activity to increase their own rate of return due to market signals. Another mechanism, useful for both consumers and catering, is to offer customers organic products with the appropriate certificates and regular and unscheduled inspections of the real quality of the products offered at the regional center of examination of environmental friendliness of food.

To take advantage of this area, one can use experience from foreign practice, namely to certify trade organizations that sell organic products and catering establishments that use only organic products in cooking, and assign them various distinctive titles, which will help increase the popularity of these institutions in the eyes of consumers.

Measures to apply organizational and communication tools to form a market of environmentally friendly products for effective demand can be presented in Figure 6.

The scheme presented in Figure 6 demonstrates the continuity in expanding the market for organic food products from stage to stage, assuming the expansion of new consumers' involvement using 
Source: Compiled by the authors for Mueller (2017), Solaiman, Osman, and Halim (2015), Razumkov centre (2019).
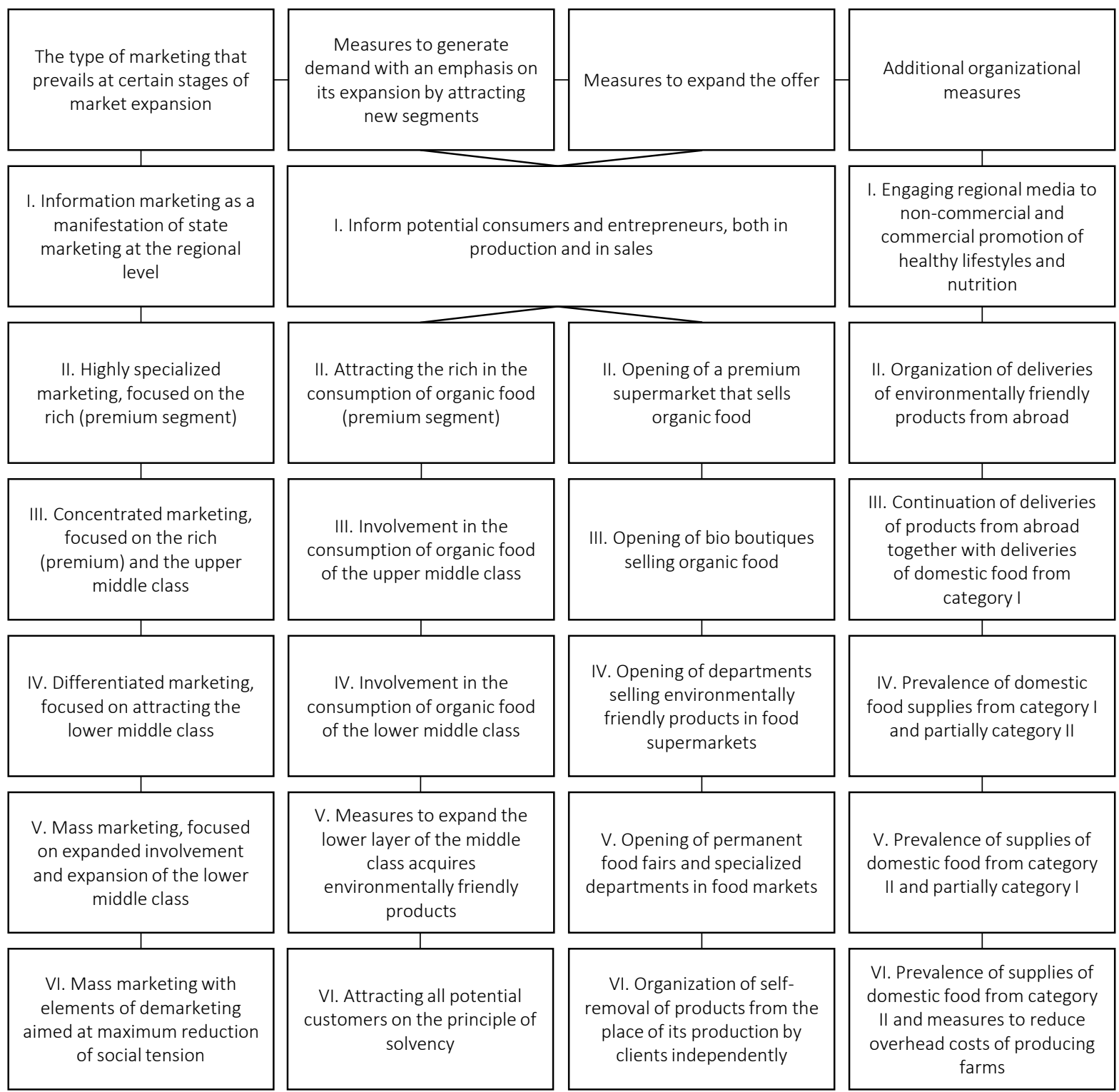

Figure 6. Stages of expanding the market for organic food in the region

marketing tools of various types. The first stage is the directed formation of public opinion about the need to lead a healthy lifestyle, present their own health as a resource, and proper nutrition as part of preserving this resource.

The transition to the second stage is justified from the moment of gaining firm confidence that some members of the premium segment are ready to buy organic food with a high price premium regularly, provided full information about purchased products and certification abroad at the place of origin. The transition to the third stage is justi- fied by obtaining reliable information about the involvement of part of the high-media segment in consumption (albeit on an irregular basis) of environmentally friendly products as customers of a premium grocery supermarket, as early followers. The transition to the maximum attraction of effective demand for environmentally friendly products is possible with the maximum reduction of the price premium for environmental friendliness. In this case, the product itself should not lose in quality, i.e., reducing the price premium is not achieved by reducing the quality of the product, but minimizing overhead costs, particularly 
storage, warehousing, transportation costs, and market entry fees. All activities to form a market for environmentally friendly products will make sense and succeed only with constant unbiased monitoring of the quality of food offered to the population. In this regard, the main role belongs to the regional center of examining the ecological purity of food.

\section{CONCLUSION}

As a result of the analysis of official statistical data, the parameters of the market of organic food products in Ukraine are defined, such as the characteristic of consumer demand with differentiation of segments on criteria of their social significance, solvency on regions and readiness to pay the price premium that allows building scientifically based tactical options. These economical tools help expand the market for organic products in the regions. Based on the analysis for balanced development of the market of ecologically pure food and an exception of unfair competition in this sphere it is offered the creation of the regional center of examination of ecological purity of production of two-level structure in the regions; at the same time, the lower level provides the deployment of the examination of harmful impurities in food products at stations of the State Sanitary and Epidemiological Service of Ukraine in the regions, and the upper level is an association of institutions (research institutes in the field of food, laboratories of examination of goods at higher educational institutions, etc.) with constant personnel and information exchange, which will allow responding quickly to consumer inquiries, increase the transparency of the product offer and the culture of service in the market of environmentally friendly products of the regions. Persistent information and use of tools of "green" technologies at each stage of expansion of the market of organic products will be directed to expanding each segment of environmentally friendly production consumers at the expense of attraction of new followers within segments. The expansion of consumption of environmentally friendly products, sales growth, and profitability will be a clear market signal for producers who will seek to expand the supply of organic products in all Ukraine's regions.

The study confirms the hypothesis, which is a scientific assumption that the use of economic and organizational tools within the concept of socio-ethical marketing will quickly take into account the dynamics of effective demand for organic food, to form a market-oriented supply, differentiated by the degree of the potential of regions in the market of organic food and rationalization of consumption of organic food to minimize possible negative consequences for consumers and society as a whole, as well as the environment.

\section{AUTHOR CONTRIBUTIONS}

Conceptualization: Victoriia Dergachova, Svitlana Smerichevska.

Formal analysis: Svitlana Smerichevska.

Funding acquisition: Victoriia Dergachova.

Methodology: Tetiana Kniazieva.

Project administration: Victoriia Dergachova.

Resources: Serhii Smerichevskyi, Tetiana Kniazieva.

Supervision: Serhii Smerichevskyi.

Validation: Serhii Smerichevskyi.

Visualization: Tetiana Kniazieva, Svitlana Smerichevska.

Writing - original draft: Tetiana Kniazieva, Svitlana Smerichevska.

Writing - review \& editing: Victoriia Dergachova, Serhii Smerichevskyi. 


\section{REFERENCES}

1. Ahropromyslovyi kompleks Ukrainy (Agro-industrial complex of Ukraine). (n.d.). Informatsiinoanalitichnyi portal [Information-analytical portal of the Agro-industrial complex of Ukraine]. (In Ukrainian) Retrieved from https://agro.me.gov. ua/ua

2. Agustini, M. H., Athanasius, S., \& Retnawati, B. (2019). Identification of green marketing strategies: perspective of a developing country. Innovative Marketing, 15(4), 42-56. http://doi.org/10.21511/ im.15(4).2019.04

3. Govender, J. P., \& Govender, T. L. (2016). The influence of green marketing on consumer purchase behavior. Environmental Economics, 7(2), 77-85. http://doi.org/10.21511/ ee. $07(2) .2016 .8$

4. Kumar, P., \& Ghodeswar, B. M. (2015). Factors Affecting Consumers' Green Product Purchase Decisions. Marketing Intelligence \& Planning, 33(3), 330-347. https://doi. org/10.1108/MIP-03-2014-0068

5. Lane, D. C. (2006). IFORS' Operational Research Hall of Fame Jay Wright Forrester. International Transactions in $O p$ erational Research, 13(5), 483-492. https://doi.org/10.1111/j.14753995.2006.00559.x

6. Legislation of Ukraine. (2019). Pro Osnovni zasady (stratehii) derzhavnoi ekolohichnoi polityky Ukraini na period do 2030 roku. Zakon Ukrainy vid 28.02.2019 No. 2697-VIII [Basic principles (strategy) of the state ecological policy of Ukraine for the period till 2030. Law of Ukraine dated February 28, 2019 No. 2697-VIII]. Vidomosti Verkhovnoi Rady (VVR), 16, st. 70. (In Ukrainian). Retrieved from https://zakon.rada.gov.ua/laws/ show/2697-19

7. Lin, C.-J., \& Chen, H.-Y. (2016) User Expectancies for Green Products: A Case Study on the Internal Customers of a Social Enterprise. Social Enterprise Journal, 13(3), 281301. https://doi.org/10.1108/SEJ-022016-0004

8. Meadows, D. L. (1977). Alternatives to growth: a search for sustainable futures (405 p.). Cambridge: Ballinger Publisher.

9. Mostovaya, J. (2017). Organika, eko, ili bio: otlichiya i preimushchestva [Organics, eco, or bio: differences and benefits]. (In Russian). Retrieved from https://trademaster.ua/ryinki_food/312365

10. Mueller, S. (2017). Green technology and its effect on the modern world (Bachelor's Thesis). Oulu University of Applied Sciences. Retrieved from https://core.ac.uk/download/ pdf/84793641.pdf

11. Pirozhok, O. (2019, April, 3). Khto $v$ Ukraini vyrobliae spravzhniu orhanichnu produktsiiu [Who produces real organic products in Ukraine]. (In Ukrainian). Retrieved from https://www.epravda.com.ua/ publications/2019/04/3/646613/ (accessed on May 30, 2020)

12. Potapenko, V., Kornatovskyy, R. B., \& Shylkina, A. L. (2017). "Zelena” modernizatsiia ekonomiky Ukrainy: sotsio-ekonomichne doslidzhennia ["Green" economy modernization of Ukraine: socio-economic study]. Marketynh i menedzhment innovatsii - Marketing and management of innovations, 2, 344-358. (In Ukrainian). Retrieved from https://mmi.fem. sumdu.edu.ua/sites/default/files/ mmi2017_2_344_358.pdf

13. Potapenko, V., Khlobystov, Ye., \& Kornatowski, R. (2017) Green modernization of Ukraine's economy: analysis of barriers and drivers based on interviewing of the companies. Environmental Economics, 8(2), 50-56. http://dx.doi. org/10.21511/ee.08(2).2017.05

14. Razumkov centre. (2019). "Zeleni" investytsii u stalomu rozvytku: svitovyi dosvid ta ukrainskyi kontekst ["Green" investments in sustainable development: world experience and the Ukrainian context]. Analytical report. (In Ukrainian). Retrieved from http://razumkov.org.ua/ uploads/article/2019_ZELEN_INVEST.pdf

15. Solaiman, M., Osman, A., \& Halim, M. S. (2015). Green Marketing: A Marketing Mix Point of View. International Journal of Business and Technopreneurship, 5(1),
87-98. Retrieved from http:// dspace.unimap.edu.my/xmlui/bitstream/handle/123456789/40027/ IJBT_Vol_5_Feb_2015_7_87-98. pdf? sequence $=1$

16. State Statistics Service of Ukraine. (2019a). Statistical publication. Regions of Ukraine. (In Ukrainian). Retrieved from http://www.ukrstat. gov.ua/druk/publicat/kat_u/2019/ zb/12/zb_ru1ch2019.pdf

17. State Statistics Service of Ukraine. (2019b). Ukraina u tsyfrakh 2018. Statystychnyi shchorichnik [Ukraine in numbers 2018. Statistical Yearbook]. (In Ukrainian). Retrieved from http://www.ukrstat.gov.ua/ druk/publicat/kat_u/2019/zb/07/ Ukr_cifra_2018_u.pdf

18. State Statistics Service of Ukraine. (2019c). Ukraine Households SelfPerceived of Their Income (Statistical collection). (In Ukrainian). Retrieved from http://www.ukrstat. gov.ua/druk/publicat/kat_u/2019/ zb/08/zb_sdurd2018.pdf (accessed on May 25, 2020)

19. The Ministry of Economic Development, Trade and Agriculture of Ukraine. (n.d.). Official web-site. Retrieved from https://www.me.gov. ua

20. UNEP. (n.d.). Green economy (Reference document). Retrieved from http://web.unep.org/greeneconomy/ sites/ (accessed on March 28, 2020)

21. United Nations (UN). (1992). Rio Declaration on Environment and Development. Retrieved from https://www.jus.uio.no/lm/environmental.development.rio.declaration.1992/portrait.a4.pdf

22. Williams, E. (2011). Environmental effects of information and communications technologies. Nature, 479(7373), 354-358. Retrieved from https://www.nature. com/articles/nature10682

23. World Commission on Environment and Development (WCED). (1987). Our Common Future (Report). Oxford: Oxford University Press. Retrieved from https://sustainabledevelopment.un.org/content/ documents/5987our-commonfuture.pdf 